\title{
心血管保護薬としてのスタチンの多面的作用
}

\author{
平瀬徹明*・野出孝一 \\ 佐賀大学医学部＼cjkstart循環器・腎臓内科％ 849-8501 佐賀市鍋島 5-1-1
}

\section{Pleiotropic Effects of Statin in Cardiovascular Protection}

\author{
Tetsuaki Hirase* and Koichi Node \\ Department of Cardiovascular and Renal Medicine, Saga University Faculty of Medicine \\ 5-1-1 Nabeshima, Saga 849-8501, Japan
}

\begin{abstract}
Statin inhibits HMG CoA reductase in cholesterol biosynthesis and lowers cholesterol levels in blood. It has been established by a lot of clinical studies that statin has protective effects against cardiovascular diseases. Experimental studies have shown that statin inhibits membrane translocation of Rho and Ras GTPases that results in activation, by decreasing cellular levels of isoprenoid intermediates. Inhibition of Rho by statin increases VEGF expression in endothelial cells that promotes cell survival. Statin also prevents endothelial hyperpermeability that is implicated in atherogenesis. Ras-mediated activation of $\mathrm{T}$ type calcium channel that may result in endothelial cell dysfunction is blocked by statin. Accordingly, statin has pleiotropic effects on cardiovascular cell function by modulating cell signaling.
\end{abstract}

Key words : statin / isoprenoid / Rho / Ras / endothelial cells

\section{1. はじめに}

スタチンは,アセチル CoAからメバロン酸, スク アレンを経由して内因性のコレステロールを生合成 するメバロン酸経路における律速段階酵素である HMG-CoA reductaseに対する阻害剂であり, 高コレ ステロール血症に対する治療薬として開発された (Fig. 1). スタチンは多くの大規模臨床試験において 冠動脈疾患や脳血管障害の発症リスクを低下させる 心血管保護作用を有することが明らかにされてきた が，その作用の一部は血中コレステロール低下作用 に依存しない可能性が指摘されている ${ }^{1}$ 。 一方，スタ チンは細胞内シグナルに直接作用し多彩な細胞機能 を修飾することによって血管内皮機能の改善, 血管

* Correspondig author

Tel : 0952-34-2364

Fax : 0952-34-2089

E-mail : hiraset@med.saga-u.ac.jp
平滑筋増殖抑制作用, 血栓形成抑制作用, 抗炎症作 用，血管形成促進作用といった多面的作用を有する ことが実験研究により明らかになってきた ${ }^{2}$.

血管内皮細胞は一層の細胞層を形成し，血液成分 と血管壁のインターフェイスとして機能している。 内皮細胞は, 一酸化窒素・プロスタサイクリン・内 皮依存性過分極因子といった血管弛緩因子やエンド セリン等の血管収縮因子を産生することで能動的に 内皮依存性血管弛緩反応を調節し，血流制御に貢献 している. 内皮細胞は凝固・線溶関連因子を産生し, また白血球を介した活性化血小板との相互作用によ り血管壁における凝固・線溶調節に関与している. さらに内皮細胞はバリアーとして血管壁への血液成 分の漏出や血球の遊走を制御することによって, 組 織恒常性の維持及び炎症反応制御を行っている.以 上のように, 内皮細胞は多彩かつ重要な血管生理機 能の調節に関与するのみならず, 内皮細胞機能の障 害が動脈硬化をはじめとする血管障害の病態形成に 重要な役割を果たすと考えられている3 ${ }^{3}$.したがって, 


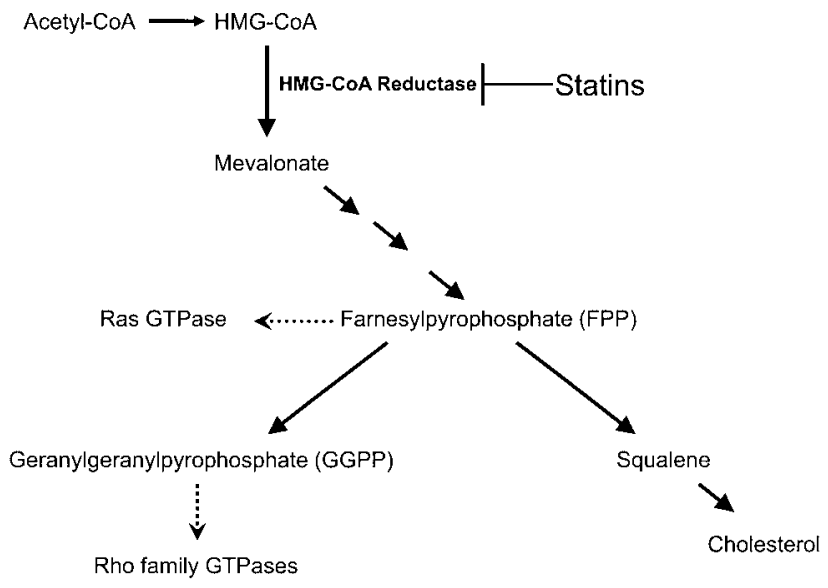

Fig. 1 Cholesterol biosynthesis and statin.

スタチンの内皮細胞機能に対する作用を検討するこ とは，心血管保護におけるスタチンの作用を理解す るうえで重要であると考える.

本稿では，まず始めにスタチンによる低分子量 $\mathrm{G}$ 蛋白質 Rho ・ Ras の活性調節機構について概説し, 次に Rho による血管内皮細胞透過性調節やvascular endothelial growth factor (VEGF) 産生調節と Rasに よる血管内皮細胞増殖・遊走制御に対するスタチン の作用について我々が得た実験的知見に基づき考察 する.

\section{2. スタチンによる低分子量 $G$ 蛋白質 Rho 及 びRasの活性調節機構}

臨床研究によりスタチンによる心血管保護作用が スタチン投与開始後比較的早期から，また血中コレ ステロール低下によって期待されるよりも大きく認 められたことから，スタチンの心血管細胞に対する 直接作用が想定された．Laufs らは，培養ヒト内皮細 胞において低分子量 $\mathrm{G}$ 蛋白質 Rho 及び Ras がスタチ ンにより細胞膜分画において減少し細胞質分画にお いて増加することを示した ${ }^{4)}$. 彼らはスタチンがメバ ロン酸経路を抑制する結果イソプレノイド中間代謝 産物 geranylgeranylpyrophosphate（GGPP）及び farnesylpyrophosphate（FPP）の細胞内レベルが減少す ることに着目し，GGPPの同時添加が Rho に対する スタチンの作用を, FPPの同時添加が Rasに対する スタチンの作用を減弱させることを明らかにした。 Rho 及びRas は不活性型である GDP 結合フォームと して細胞質に相対的に多く存在し, Rho は GGPPの 存在下に geranylgeranyl transferaseにより geranylgeranyl化され， RasはFPPの存在下に farnesyl transferaseにより farnesyl化され細胞膜へ移行する．細胞 膜へ移行したRho及び Ras はそれぞれに対する gua-

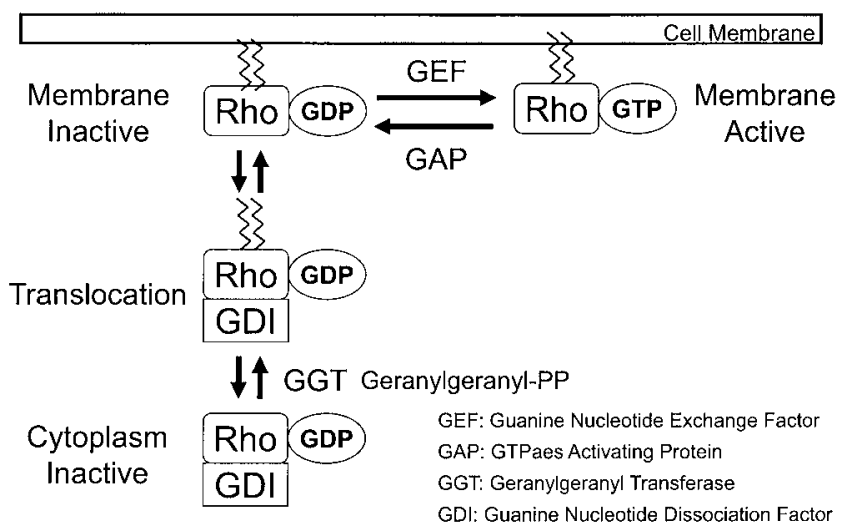

Fig. 2 Geranylgeranylation is necessary for membrane translocation and activation of Rho GTPase.

nine nucleotide exchange factorにより活性型である GTP結合フォームに変換され, シグナル伝達に関与 する. 活性型 Rho 及びRas は速やかにそれぞれに対 する GTPase activating proteinにより加水分解される ことにより不活性型である GDP結合フォームに変換 され，シグナル伝達を終了する (Fig. 2).

以上のように，シグナル伝達における Rho及びRas の活性化においてイソプレノイド中間代謝産物の存 在下での細胞膜への移行は必須であり, スタチンは 細胞内のイソプレノイド中間代謝産物レベルを減少 させることでRho及びRas の活性化を抑制すると考 えられる. 実際, スタチンによるRhoの細胞膜への 移行と活性化の抑制が培養ヒト内皮細胞において内 皮型一酸化窒素合成酵素（eNOS）の遺伝子発現を増 加させることが示されている4).

\section{Rhoによる血管内皮細胞タイトジャンク ション透過性調節とスタチン}

近年動脈硬化は血管細胞及び免疫細胞が関与した 血管壁の慢性炎症としてとらえられ，最も早期に観 察される変化としては内皮細胞の活性化による透過 性の充進に起因する血液中の蛋白質・脂質の血管壁 への漏出と白血球の内皮下への遊走であると考えら れている ${ }^{5)}$. 脂質異常症に合併する動脈硬化のモデル であるWHHLウサギにおいて, 大動脈血管壁の血液 中の蛋白質に対する透過性が充進していることが明 らかとなっている6). 血管壁透過性を調節している内 皮細胞のバリアー機能においては, 内皮細胞間接着 部位に存在する細胞間接着装置タイトジャンクショ ンによる細胞間隙を通過する血液中分子の移動制御 が重要な役割を果たしている．タイトジャンクショ ンは occludin や claudin等の内在性膜蛋白質と, アク チン細胞骨格と結合したZO-1等の細胞膜裏打ち蛋白 


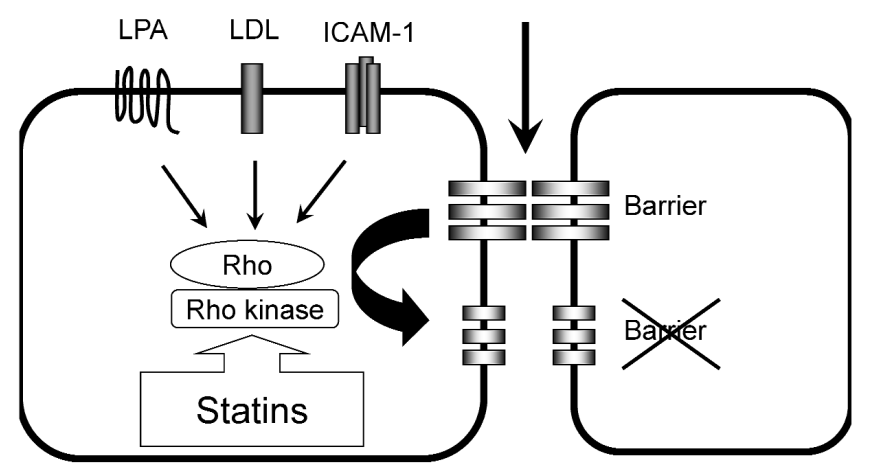

Fig. 3 Endothelial barrier dysfunction induced by Rho and Rho kinase is blocked by statins.

質から構成される蛋白質複合体によりその機能が制 御されている7).

リゾフォスファチジン酸（LPA）はヒト動脈硬化 巣に豊富に存在するリゾリン脂質で, 細胞膜に存在 する受容体を介し多彩な生理活性を示す。培養ヒト 内皮細胞における我々の検討では，LPAは occludin の燐酸化とタイトジャンクション透過性の克進を生 じた。これらはRho及びRho kinaseに対する dominant negative変異体の過剩発現や Rho kinase阻害剂 で抑制されたことから，Rho及びRho kinaseが occludin の燐酸化とタイトジャンクション透過性の克 進を制御することが明らかとなった ${ }^{8}$. また白血球と 内皮細胞は接着分子を介して接着すると双方向性に 細胞内シグナルが活性化される.内皮細胞膜に発現 する接着分子 ICAM-1により活性化されるシグナル について抗体を用いた ICAM-1 クロスリンキングに より検討したところ，ICAM-1 活性化は Rho及び Rho kinaseを介して内皮細胞透過性の亢進と occludin の 燐酸化を生じた。

以上の結果から，動脈硬化病変形成初期における 血管透過性亢進による血液中分子の漏出と白血球の 血管壁への遊走には，Rho及びRho kinaseを介した 内皮細胞タイトジャンクションの機能変化が関与す ると考えられる（Fig. 3).WHHLウサギにおいて動 脈硬化を発症した大動脈血管壁の透過性亢進が血中 コレステロール值に依存せずにスタチンにより抑制 されることから，スタチンによるRhoの活性化抑制 は内皮細胞タイトジャンクション機能変化の抑制を 介して動脈硬化性病変形成の抑制につながることが 示唆される.

\section{4. 血管内皮細胞における RhoによるVEGF 産生調節とスタチン}

VEGFは血管発生や，生体における血管の生存・維

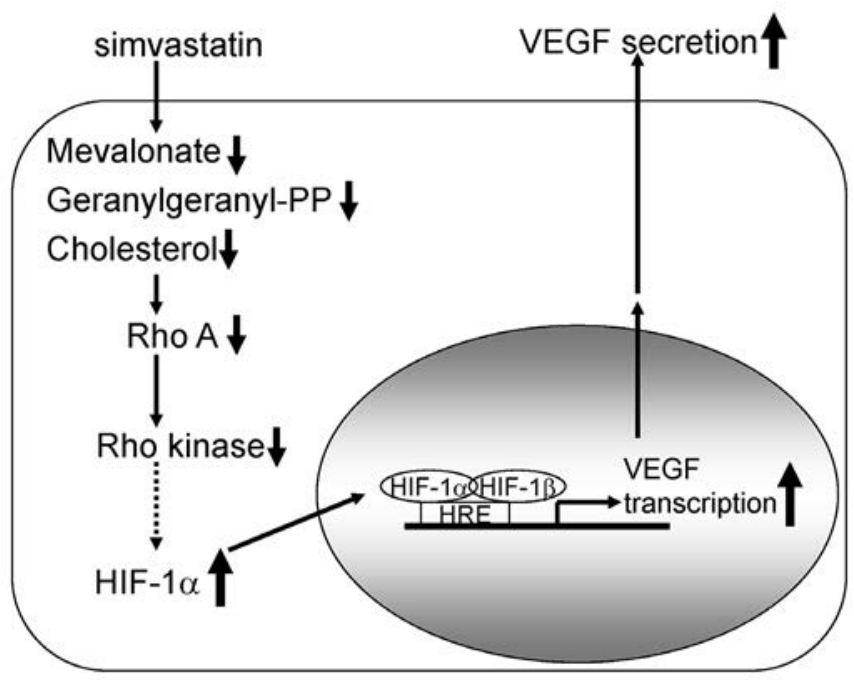

Fig. 4 Statins upregulate VEGF expression in endothelial cells.

持, 虚血組織における血管新生に重要な役割を果た す成長因子であることが知られている ${ }^{9}$. 我々は，培 養ヒト血管内皮細胞において，スタチンがVEGFの アイソフォーム $\mathrm{VEGF}_{121}$ と $\mathrm{VEGF}_{165}$ の遺伝子発現及 び蛋白質発現を増加させることを報告している ${ }^{10)}$. スタチンによるVEGF発現誘導は細胞にメバロン酸 あるいは GGPPを添加することで消失し, FPPの添 加は影響を与えなかった. Rho及びRho kinaseに対 する dominant negative変異体の過剩発現は用量依存 性にVEGF 遺伝子の発現を増加させた. VEGFの遺伝 子発現を促進する転写因子 hypoxia inducible factor $1 \alpha(\mathrm{HIF}-1 \alpha)$ をスタチンは正に, Rho 及びRho kinase は負に調節していた。 したがってスタチンは 細胞内 GGPPの産生低下から Rho 及びRho の標的分 子である Rho kinaseの活性化を抑制し, HIF-1 $\alpha$ の核 内レベルを上昇させることにより VEGF 遺伝子の発 現を増加させると考えられる (Fig. 4). 内皮細胞に おいてスタチンにより発現誘導されるVEGF 遺伝子 のレベルは平滑筋細胞等他の VEGF 産生血管細胞に 比して低いが, スタチンによる内皮細胞における低 レベルのVEGF 発現増加が血管の生存・維持, さら には血管障害の抑制に貢献すると考える.

\section{5. アンジオテンシンIIにより誘導される血 管内皮細胞増殖・遊走とスタチン}

昇圧作用を有するペプチドホルモンであるアンジ オテンシン II は, 細胞膜に発現する 1 型及び 2 型受容 体を介して細胞内シグナルを伝達する. 主に 1 型受容 体を介したシグナルは, 内皮細胞における一酸化窒 素の産生低下や病的増殖, 平滑筋細胞における増 


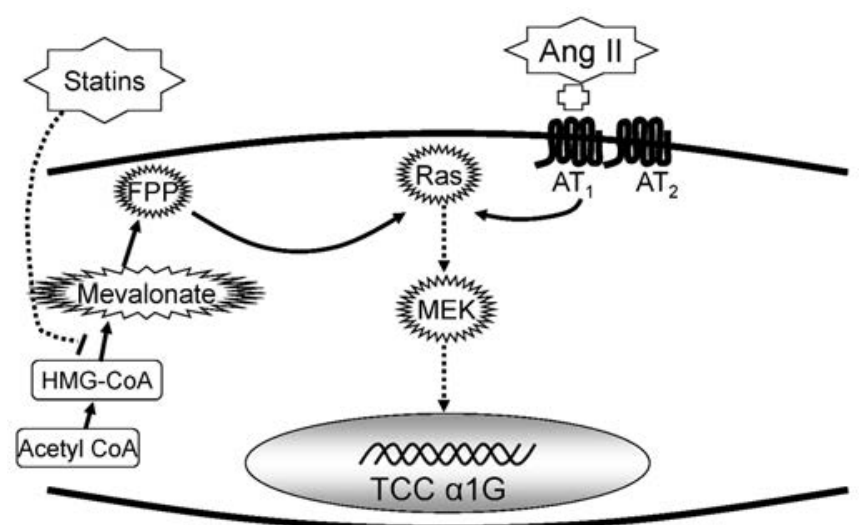

Fig. 5 Statin inhibits angiotensin II signaling mediated by Ras in endothelial cells.

殖・遊走や活性酸素種の産生促進，心筋細胞肥大を 生じ，動脈硬化を含む血管障害の促進や心筋肥大か ら心不全への進展に関与することが多くの研究によ り明らかにされてきた11).

我々は, 培養内皮細胞シートをスクラッチにより 機械的に部分剥離し，その後の内皮細胞の増殖・遊 走を観察した．アンジオテンシン II は内皮細胞の増 殖・遊走を促進したが，スタチンはこれを部分的に 抑制した.アンジオテンシン IIにより誘導される内 皮細胞の増殖・遊走を制御するシグナルのうちスタ チン感受性のシグナルについて検討を行った. T型カ ルシウムチャンネル阻害薬である mibefradil はアンジ オテンシン II により誘導される内皮細胞の増殖・遊 走を抑制したが，L型カルシウムチャンネル阻害薬 nifedipine は同様の作用を示さなかったことから，ア ンジオテンシン II により誘導される内皮細胞の増 殖・遊走に T型カルシウムチャンネル活性が関与す ることが示唆された ${ }^{12)}$. T型及び $\mathrm{L}$ 型カルシウムチャ ンネルを構成するコンポーネントのうち, T型カルシ ウムチャンネルを構成する $\alpha 1 \mathrm{G}$ の遺伝子発現のみが 培養ヒト血管内皮細胞において検出され， $\alpha 1 \mathrm{G}$ 遺伝 子発現はアンジオテンシン IIにより増加した。 アン ジオテンシン IIによる $\alpha 1 \mathrm{G}$ 遺伝子発現誘導は選択的 阻害剤を用いた薬理学的検討によりアンジオテンシ ンII 1 型受容体を介していることが明らかとなった. またアンジオテンシン II による $\alpha 1 \mathrm{G}$ 遺伝子発現誘導 はスタチンにより抑制されたが，このスタチンの作 用はメバロン酸あるいはFPPの添加により消去され た. 内皮細胞においてアンジオテンシン II は活性型 である GTP結合型 Rasを増加させ，スタチンはこれ を抑制した. Rasの下流分子である MEKに対する阻 害剂はまた $\alpha 1 \mathrm{G}$ 遺伝子の発現を抑制した。以上から, アンジオテンシン II は 1 型受容体を介して Ras-MEK

\section{Vascular Endothelial Cells}

$$
\begin{aligned}
& \text { VEGF Expression } \downarrow \\
& \text { Angiogenesis } \downarrow
\end{aligned}
$$

Impaired Vascular
Function

\section{Rho GTPase}

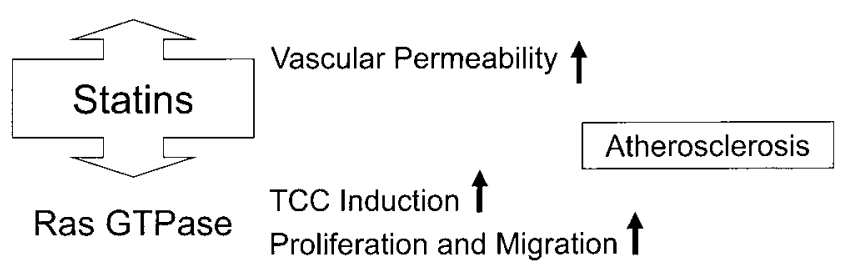

Fig. 6 Rho and Ras promote atherosclerosis by causing endothelial cell dysfunction.

経路を活性化し $\alpha 1 \mathrm{G}$ コンポーネントの発現を増加さ せることで T型カルシウムチャンネル活性を上昇さ せると考えられ，スタチンはRasを抑制することでT 型カルシウムチャンネル活性化を抑制することが示 唆された（Fig. 5). T型カルシウムチャンネルは成体 の心血管組織では生理的には活性が低いが, 内皮細 胞における活性酸素種の産生促進や平滑筋の増殖, 心筋肥大や心不全の進展に関与することが示されて いることから, 病的心血管組織においては T型カル シウムチャンネルが活性化されている可能性が考え られ，スタチンによるT型カルシウムチャンネル抑 制作用の血管障害防止における有用性が示唆される.

\section{6. おわりに}

低分子量 $\mathrm{G}$ 蛋白質 Rho 及び Ras の細胞膜への移 行・活性化の抑制に加えて, 内皮細胞においてスタ チンがホスファチジルイノシトール 3 キナーゼ $\left(\mathrm{PI}_{3} \mathrm{~K}\right)$ 依存性にセリン・スレオニンリン酸化酵素Aktの細 胞膜への移行を促進することにより活性化すること が示されている ${ }^{13)}$. 細胞へのメバロン酸の投与によ ってスタチンによる Aktの細胞膜への移行が抑制さ れることから, 細胞内コレステロール量がスタチン によるAkt活性化の重要な規定因子であると考えら れる.またスタチンが eNOS とシャペロンである hsp90の複合体への Akt の動員とAktの標的である eNOSの燐酸化を促進することが示されている ${ }^{14)}$ 。こ れらのことから，スタチンは細胞内コレステロール 量の低下を介して細胞膜での蛋白質相互作用を変化 させることにより $\mathrm{PI}_{3} \mathrm{~K}-\mathrm{Akt}$ 経路を活性化すると考え られる.

以上のように, スタチンはコレステロール生合成 阻害によるコレステロール低下作用とともに, イソ 
プレノイド中間代謝産物合成阻害を介した低分子量 G 蛋白質の活性抑制や $\mathrm{PI}_{3} \mathrm{~K}-\mathrm{Akt}$ 経路の活性化により 細胞内シグナルに作用し, 多彩な細胞機能を修飾す る結果多面的作用を発揮していると考えられる (Fig. 6). その多面性は血管内皮細胞機能の改善, 平 滑筋増殖抑制作用，血栓形成抑制作用，抗炎症作用 から血管形成促進作用まで広がっている. 今後スタ チンの細胞機能への作用がさらに解明され, それに 基づいて心血管病に対する臨床効果の検討が進むこ とが期待される.

\section{文献}

1) Mills EJ, Rachlis B, Wu P, Devereaux PJ, Arora P, Perri D : J. Am. Coll. Cardiol., 52 1769-1781 (2008)

2) Takemoto M, Liao JK : Arterioscler. Thromb. Vasc. Biol., 21, 1712-1719 (2001)

3) 平瀬徹明, 野出孝一 : 循環器科 動脈硬化のすべて, 59 (Suppl. 3), 21-24 (2006)

4) Laufs U, Liao JK : J. Biol. Chem., 273, 24266-24271 (1998)

5) Ross R: N. Engl. J. Med., 340, 115-126 (1999)

6) van Nieuw Amerongen GP, Vermeer MA, Nègre-Aminou P, Lankelma J, Emeis JJ, van Hinsbergh VW : Circulation, 102, 2803-2809 (2000)

7) Tsukita S, Furuse M, Itoh M : Nat. Rev. Mol. Cell. Biol., 2, 285-293 (2001)

8) Hirase T, Kawashima S, Wong EY, Ueyama T, Rikitake Y, Tsukita S, Yokoyama M, Staddon JM : J. Biol. Chem., 276, 10423-10431 (2001)

9) Robinson CJ, Stringer SE : J. Cell. Sci., 114, 853-865 (2001)

10) Nishimoto-Hazuku A, Hirase T, Ide N, Ikeda $Y$, Node $K$ : J. Cardiovasc. Pharmacol., 51, 267-273 (2008)

11) Mehta PK, Griendling KK : Am. J. Physiol. Cell. Physiol., 292, C82-C97 (2007)

12) Wang D, Hirase T, Inoue T, Node K : Biochem. Biophys. Res. Commun., 347, 394-400 (2006)

13) Skaletz-Rorowski A, Lutchman M, Kureishi Y, Lefer DJ, Faust JR, Walsh K : Cardiovasc. Res., 57, 253-264 (2003)

14) Brouet $A$, Sonveaux $P$, Dessy $C$, Moniotte $S$, Balligand JL, Feron O : Circ. Res., 89, 866-873 (2001)

(Received 7 July 2009;

Accepted 5 August 2009)

著者略歴

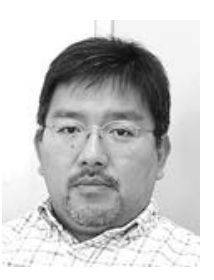

平瀬 徹明（ひらせ てつあき）

1989年 3 月 神戸大学医学部卒業

1992 年 6 月 岡崎国立共同研究機

構生理学研究所 特

別研究学生

1995年 8月 Visiting Scientist,

Eisai London Re- search Laboratories, University College London

1997 年 3 月 神戸大学大学院医学 研究科博士課程修了

2003 年 7 月 佐賀医科大学循環器 内科 助手

2007 年 4 月 佐賀大学医学部循環 器内科 助教

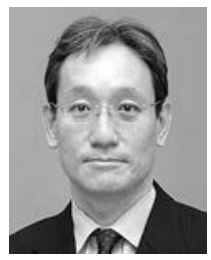

$\begin{array}{ll}\text { 野出 孝一 (ので こういち }) \\ \text { 1989年 } & \text { 佐賀医科大学卒業 } \\ \text { 1997年 } & \text { 大阪大学大学院修了 } \\ 1997 \text { 年 } & \text { ハーバード大学留学 } \\ 2002 \text { 年 } & \text { 佐賀医科大学内科学 } \\ & \text { 教授 } \\ 2003 \text { 年 } & \text { 佐賀大学内科学 教 } \\ & \text { 授 } \\ \text { 2008年 } & \text { 佐賀大学病院 ハー } \\ & \text { トセンター長 } \\ \text { 2008年 } & \text { 佐賀大学 病院長特 } \\ & \text { 別補佐 }\end{array}$

